\title{
Assessment of Oral Health Status among Orphanage Children (Underprivileged Population): A Descriptive Cross-Sectional Study
}

\author{
RAM KUMAR SINGH'1, RAJ GOURAV'12, SIMPLE KAUR², DAISY NAIDU1
}

INTRODUCTION: An orphan is a child under 18 year who has lost both parents or has been abandoned by them. Such children are deprived of the parental love and care and get little health care as well as their oral cavity is generally neglected.

AIM: To assess the dental caries experience, oral hygiene status and periodontal status among the orphanage children in Prakasam District, Andhra Pradesh, India.

MATERIALS AND METHOD: A cross sectional study among 485 orphan children of various institutes ranged from 12 to 16 years where WHO oral health assessment form 2013 was used and chi- square test and descriptive statistics test were used for statistical analysis by using SPSS 22.0 software.

RESULTS: It was seen that $73.4 \%$ were having dental caries and the mean DI-S scores, CI-S scores and OHI-S scores were 1.41 $\pm 0.47,1.07 \pm 0.47$ and 2.48 \pm 0.92 respectively. The prevalence and severity of gingival bleeding was found to be more i.e. $64.7 \%$ among them.

CONCLUSION: Majority of orphan children were suffering from oral problems. Oral health fraternity should actively involve with other parts of the community in order to maintain oral care of this group.

KEYWORDS: Dental Caries, Oral Health, Orphanage, Children, Periodontal.

\section{INTRODUCTION}

Despite immense improvements in the oral health of populations various worldwide1 problems still persist such as dental decay, periodontal conditions, tooth loss, etc. ${ }^{1-3}$ Oral disease pattern is dependent on various socioeconomic characteristics like social, cultural, economic and ethnic factors. ${ }^{4,5}$ It has been said through various studies that parents are the primary caretakers and saviours of a child which greatly influence the development of general and health related behaviour. However, there is a section in the society where unhappily many of the children have to lead their lives without parents, the later either being dead or incapable of bringing up their children, such section of the society is called as orphans. ${ }^{6,7}$ An orphan is a child under 18 year who has lost both parents or has been abandoned by them. ${ }^{8}$ Such children are deprived of the parental love and care which is received by those living with their parents. ${ }^{9}$

The orphans get little health care and oral cavity is the most neglected aspect of children living in orphanage. ${ }^{10}$ In these children, absence of family support might influence their oral health behaviour which lead to poor quality of life." Even few studies also reported that children in orphanages revealed a high prevalence of dental caries, dental trauma and gingivitis. ${ }^{12,13}$ Poor oral health among these children can be associated with a number of factors, including uneven and limited access to oral health care, lack of quality measures in oral health care, inadequate health literacy, and lack of attention to oral health among primary care providers. ${ }^{14}$ Poor living conditions in orphanages where children live might also be related to many complex oral health problems. ${ }^{15}$ Thus, acquiring information on the medical and dental health status of orphan children will help to provide a better understanding of the medical and dental health problems of an overlooked segment of the society. It will also help in preventing and determining the treatment needs that suit this population. Very few studies have been reported in India so far in order to assess the oral health status of the orphan children. Thus, the present descriptive cross-sectional study was carried out with aim to assess the oral health status of orphan children.

\section{MATERIALS AND METHOD}

Study setting and population: A cross-sectional descriptive epidemiological survey was carried out to assess and the dental caries experience using dentition status and treatment needs, Oral Hygiene Status using Simplified Oral Hygiene Index, periodontal status using CPI index using WHO Proforma 2013 among the 485 orphanage children aged from 12 to 16 years among orphanages in Prakasam District, Andhra Pradesh, 
India by using stratified cluster random sampling technique.

\section{Inclusion Criterion:}

a. Children who had given informed consent were examined.

b. Children who are present on the day of examination.

\section{Exclusion criteria:}

a. Children who refused for the dental check-up and where it was difficult to carry out were excluded from the study.

b. Children who are intellectually disabled.

Ethical clearance and institution consent: Prior to the start of the study, ethical clearance for the present study was obtained after presenting the brief protocol of the study and before the start of the survey, official permission was obtained from head of the orphanages after duly explaining the purpose and methodology of the study. Later on, a written informed consent was obtained from the caretakers of the study participants.

Statistical Analysis: The recorded data was entered in the Microsoft Excel and analyzed using the SPSS Version 22.o. Descriptive statistics that included mean, standard deviation and percentages and chi square tests were calculated for each of the categories. Level of significance was fixed at 0.05 or less.

\section{RESULTS}

In this cross-sectional study, 104(21.5\%) were in 12-14 year age group, $213(43.9 \%)$ were in $14-16$ year age group and $168(34.6 \%)$ were in $16-18$ years age group. It was also seen that majority of the subjects $472(97.3 \%)$ had no past dental visit. Only $13(2.7 \%)$ had visited dentist once/year (Table 1).

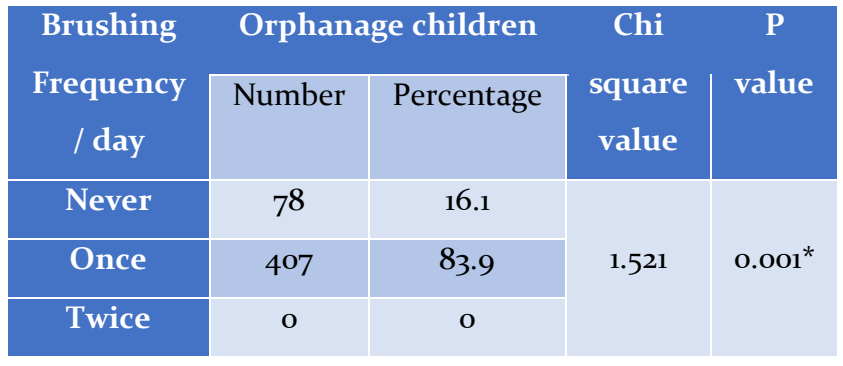

Table 1. Brushing Practices Among Orphans

The use of oral hygiene aids among orphans is depicted in table 2. A majority of the orphans $(74 \%)$ used toothbrush with toothpaste, while the least $(0.2 \%)$ used toothbrush with powder. Alarmingly, still 13.6\% and $12.2 \%$ of orphans were using toothpaste and powder with their finger. These observations were found to be statistically significant $(\mathrm{p}=003)$.

\begin{tabular}{|c|c|c|c|c|}
\hline \multirow{2}{*}{$\begin{array}{c}\text { Oral } \\
\text { Hygiene } \\
\text { Practice }\end{array}$} & \multicolumn{2}{|c|}{ Orphanage children } & \multirow{2}{*}{$\begin{array}{c}\text { Chi } \\
\text { Square } \\
\text { value }\end{array}$} & \multirow[t]{2}{*}{$\begin{array}{c}\mathbf{P} \\
\text { value }\end{array}$} \\
\hline & Number & Percentage & & \\
\hline $\begin{array}{l}\text { Toothbrush } \\
\text { with } \\
\text { toothpaste }\end{array}$ & 359 & 74 & & \\
\hline $\begin{array}{c}\text { Toothbrush } \\
\text { with } \\
\text { powder }\end{array}$ & 1 & 0.2 & 2.12 & $0.003^{*}$ \\
\hline $\begin{array}{l}\text { Finger with } \\
\text { toothpaste }\end{array}$ & 66 & 13.6 & & \\
\hline $\begin{array}{c}\text { Finger with } \\
\text { powder }\end{array}$ & 59 & 12.2 & & \\
\hline
\end{tabular}

Table 2. Use Of Oral Hygiene Aids Among Orphans

Dental caries (table 3) was observed in $73.6 \%$ of the orphans with a mean DMFT of 1.32 \pm 1.12 . The differences were found to be statistically significant $(\mathrm{p}=0.002)$.

\begin{tabular}{|c|c|c|c|c|c|}
\hline \multirow{2}{*}{$\begin{array}{l}\text { Dental } \\
\text { Caries }\end{array}$} & \multicolumn{2}{|c|}{ Orphanage children } & \multirow{2}{*}{$\begin{array}{l}\text { Chi } \\
\text { square } \\
\text { value }\end{array}$} & \multirow{2}{*}{$\underset{\text { value }}{\mathbf{p}}$} & \multirow{2}{*}{$\begin{array}{l}\text { Mean } \\
\text { DMFT }\end{array}$} \\
\hline & Number & Percentage & & & \\
\hline Absent & 129 & 26.6 & \multirow[b]{2}{*}{2.229} & \multirow[b]{2}{*}{$0.002^{*}$} & \multirow{2}{*}{$1.32 \pm 1.12$} \\
\hline Present & 356 & 73.4 & & & \\
\hline
\end{tabular}

Table 3. Dental Caries Among Orphans

Upon assessment of the oral hygiene scores based on OHI-S, most orphans reported a "good" DI-S score (46.4\%), followed by "fair" CI-S scores (43.7\%) and "poor" OHI-S scores (51.1\%) and is depicted in table 4 .

Assessment of gingival bleeding scores among the orphans (table 5) revealed the presence of bleeding in $64.7 \%$ of the orphans and this difference was found to be statistically significant (p-0.002)

\section{DISCUSSION}

The orphans are socially and economically deprived and they rarely get an opportunity to seek dental care. The orphans get little health care and oral cavity is the 


\begin{tabular}{|c|c|c|c|c|c|}
\hline \multirow{2}{*}{$\begin{array}{l}\text { Oral Hygiene Index } \\
\text { (S) Scores }\end{array}$} & \multicolumn{2}{|c|}{ Orphanage children } & \multirow{2}{*}{$\begin{array}{l}\text { Level of Oral } \\
\text { Hygiene }\end{array}$} & \multirow[t]{2}{*}{ Number } & \multirow[b]{2}{*}{ Percentage } \\
\hline & Mean & $\begin{array}{l}\text { Standard } \\
\text { Deviation }\end{array}$ & & & \\
\hline DI-S Score & 1.41 & 0.47 & Good & 225 & 46.4 \\
\hline CI-S Score & 1.07 & 0.47 & Fair & 212 & 43.7 \\
\hline OHI-S Score & 2.48 & 0.92 & Poor & 248 & 51.1 \\
\hline
\end{tabular}

Table 4. Oral Hygiene Scores Based On OHI-S And Level of Oral Hygiene Among Orphans

most neglected aspect of children living in an orphanage. ${ }^{12}$ This cross-sectional study consisted of 485 orphans and the majority of study group, were aged 14-16 years age group i.e. $43.9 \%$ with mean age of the orphanage children was $14.75 \pm 1.87$ years. This finding is in agreement with the study done by Sharma A et al.(2014) $)^{16}$ in Jaipur and Al Maweri et al.(2014) $)^{13}$ in Yemen in which the majority of the study participants were aged 15 years. The information on past dental history revealed that $97.3 \%$ orphanage children had never consulted the dentist as of lack of awareness about the significance of oral health among orphanage children and their care takers may be not taking oral care into serious consideration which influence the dental service utilization.

\begin{tabular}{|c|c|c|c|c|}
\hline \multirow{2}{*}{$\begin{array}{l}\text { Gingival } \\
\text { Bleeding }\end{array}$} & \multicolumn{2}{|c|}{ Orphanage children } & \multirow{2}{*}{$\begin{array}{c}\text { Chi } \\
\text { Square } \\
\text { Value }\end{array}$} & \multirow{2}{*}{ p Value } \\
\hline & Number & Percentage & & \\
\hline Present & 314 & 64.7 & \multirow{2}{*}{5.155} & \multirow{2}{*}{$\begin{array}{c}\text { o.oo2 }^{*} \\
\text { (Significant) }\end{array}$} \\
\hline Absent & 171 & $35 \cdot 3$ & & \\
\hline
\end{tabular}

Table 5. Orphans with Presence and Absence of Gingival Bleeding

It was observed through this study that $73.4 \%$ of the orphanage children had decayed teeth with mean DMFT $1.32 \pm 1.12$ at statically significant level and results are in agreement with study done by Al-Obaidullah $\mathrm{A}$ et al (2016) ${ }^{17}$ and disagreement with Mohan A et al. $(2014)^{18}$ in Lucknow where only $43.7 \%$ orphanage children were having decayed teeth. This might be due to the fact that orphanage children in India are usually engaged by various NGOs or social workers and many times they don't even realize that oral health is main and foremost part of child's wellbeing.

The present study also revealed that the mean oral hygiene index score among orphans was $2.46 \pm 1.12$. This finding is in agreement with the study conducted by AlJobair AM (2013) $)^{15}$ in Saudi Arabia. Even majority of orphanage children (68.5\%) had poor oral hygiene status which may be due to the fact that orphans children may be find difficult to maintain their own oral hygiene due to limited or unavailability of the oral hygiene products. As majority of the studied population were having poor oral hygiene which results higher prevalence of gingival bleeding too, i.e. $64.7 \%$. Thus, findings in this study highlight that the overall oral health status was poorer in orphanage children.

If good oral health is to become a reality in the future for people with special needs, it is essential that people in daily contact with the children become involved in oral care. With increasing number of people with special needs, the oral health fraternity should actively involve with other parts of the community to bring about general and social wellbeing and benefit them with sustained lifetime oral health. Further more detail studies are necessary to assess more effective modalities for proper oral health care in this population.

\section{CONCLUSION}

Majority of orphan children were suffering from oral health related problems. Most common hard tissue finding was dental caries in orphanages. To improve the oral health status a combined strategy that deals with current disease load and helps to prevent the further occurrence of disease in the long run is needed.

\section{REFRENCES}

1. Prasad AK, Shankar S, Sowmya J, Priya CV. Oral health knowledge attitude practice of school students of KSR Matriculation School, Thiruchengode. J Acquir Immune Defic Syndr.2010;1(1):5-11.

2. Petersen PE. The World Oral Health Report 2003: Continuous improvement of oral health in the 21st century - the approach of the WHO Global Oral Health Program. Community Dent Oral Epidemiol. 2003; 31(Suppl 1):3-23. 
3. Petersen PE. Oral Health. International encyclopedia of public health. $8^{\text {th }}$ edition: Academic press, 2008 .

4. Gambhir RS, Sohi RK, Nanda T, Sawhney GS, Setia S. Impact of school based oral health education programme in India: A systematic review. J Clin Diagn Res. 2013; 7(12):3107-10. https://doi.org/10.786o/JCDR/2013/6212.3718

5. Kumar DA, Varghese RK, Chaturvedi SS, Agrawal A, Fating C, Makka R. Prevalence of malocclusion among children and adolescents residing in orphanages of Bilaspur, Chattishgarh, India. J Adv Oral Res. 2012;3(3):21-8.

6. Cluver L, Gardener F, Operario D. Psychological distress among AIDS orphaned children in urban South Africa. J Child Psychol Psychiatry. 2007;48:755-63.

7. Shukla D, Shukla B. Study to Assess Physical Health Status of Children at Selected Orphanage in Salem, Chennai, India. Int Res J. 2011;1(2):1-8.

8. Kumar S, Goyal A, Tadakamadla J, Tibdewal H, Duraiswamy P, Kulkarni S. Oral health related quality of life among children with parents and those with no parents. Community Dent Health 2011;28(3):227-31.

9. O'Sullivan EA, Stephens AJ. The oral and dental status of children residing in a Romanian orphanage. Int J Paediatr Dent. 1997;7:41-2.

10. Muralidharan D, Fareed N, Shanthi M. Comprehensive dental health care program at an orphanage in Nellore district of Andhra Pradesh. Indian J Dent Res.2012;23(2):171-5.

11. Sushanth VH, Krishna M, Suresh AM, Prashant GM, Chandu GN. A peer group approach model of oral health promotion among orphans at Puduchery, South India. J Int Soc Prev Comm Dent. 2011;1(2):71-5.

12. Camacho GA, Camacho E, Rodriguez RA, Guille A, Juarez HM, Perez GM. Predisposing factors for dental caries in girls at an orphanage of Mexico City. Acta Pediatr Mex. 2009;30(2):71-6.

13. Al Maweri SA, Al Soneidar WA, Halboub ES. Oral lesions and dental status among institutionalized orphans in Yemen: A matched case control study. Contemp Clin Dent. 2014;5(1):81-4. https://doi.org/10.4103/o976-237X.128673

14. Van Damme OK, Krajewska-Kułak E, Wronska I, Szczepanski M, Kulak W, Lukaszuk C. Quality of life self-assessment of children living in a children's home, based on own research conducted in the Podlaskie Province. Adv Med Sci. 2007;52: 44-5o.

15. Al-Jobair AM et al. Medical and dental health status of orphan children in central Saudi Arabi. Saudi Med J. 2013;34(5):531-6.

16. Sharma A, Gaur A, Pareek S, Raja V, Sanadhya S, Sharma AB. Oral Health Status and Treatment Needs among Orphanage Children of Jaipur City. Sch J App Med Sci. 2014;2(5):1776-80.

17. Obaidullah AA, Towijiry BA, Osman KH. Oral health status of female orphanage adolescents compared to adolescents living with their families, Qassim, Saudi Arabia. Int J Adv Res. 2016;4(11):1664-9. http://doi.org/10.21474/IJARo1/2259

18. Mohan A, Misra N, Umapathy D, Kumar S, Srivastav D, Mohan U. Oral and Dental Health Status in Orphan Children of Lucknow. Ind J Comm Health. 2014;26(2):170-3.

\section{AUTHOR AFFILIATIONS: (*Corresponding Author)}

1. BDS, Dental Consultant Surgeons, Podili, District Prakasam, Andhra Pradesh, India.

2. BDS, Roopnagar, India.

Cite this article as:

Singh RK, Gourav R, Kaur S, Naidu D. Assessment of Oral Health Status among Orphanage Children (Underprivileged Population): A Descriptive Cross-Sectional
Study.
Int
Healthc
Res
$\mathrm{J}$. 2022;5(10):OR1-OR4

https://doi.org/10.26440/IHRJ/0510.01503 